\title{
EXPLORING PLANT ROOT-FUNGAL INTERACTIONS IN A NEOTROPICAL FRESHWATER WETLAND
}

\section{EXPLORANDO INTERACCIONES RAÍZ-HONGO EN UN HUMEDAL NEOTROPICAL DE AGUA DULCE}

\author{
Jazmín Santillán-Manjarrez ${ }^{1}$, A. Penélope Solís-Hernández², Patricia Castilla-Hernández², Ignacio E. \\ Maldonado-Mendoza ${ }^{3}$, Gilberto Vela-Correa ${ }^{2}$, Aurora Chimal-Hernández², Claudia Hernández-Díaz ${ }^{2}$, Martha \\ SignORET-PoIllon ${ }^{2}$, DiederiK VAN TUINEN ${ }^{4}$, AND FACUNDO RIVERA-BECERRIL ${ }^{2, *}$
}

\begin{abstract}
${ }^{1}$ Maestría en Ciencias Agropecuarias, Universidad Autónoma Metropolitana-Xochimilco, Mexico City, Mexico. ${ }^{2}$ Departamento El Hombre y su Ambiente, Universidad Autónoma Metropolitana-Xochimilco, Mexico City, Mexico. ${ }^{3}$ Departamento de Biotecnología Agrícola, CIIDIR-Unidad Sinaloa, IPN, Guasave Sin., Mexico.

${ }^{4}$ UMR1347 Agroécologie, AgroSup Dijon, CNRS, INRA, Université Bourgogne Franche-Comté, Dijon, France.
\end{abstract}

*Corresponding author: frivera@correo.xoc.uam.mx

\begin{abstract}
Background: Wetlands in Neotropics harbor high fungal diversity, including arbuscular mycorrhizal fungi (AMF) and dark septate endophytes (DSE). This study describes the interaction of plant roots with AMF and DSE in a freshwater wetland belonging to a hotspot of biodiversity.

Hypothesis: Differential root colonization between arbuscular mycorrhizal and dark septate endophyte fungi is influenced by plant species and abiotic conditions in a freshwater wetland.

Studied species: Plant species colonized by arbuscular mycorrhizal and dark septate endophyte fungi.

Methods: Properties of soils and the water column, floristic composition, root colonization by AMF and DSE, and molecular identification of AMF inside roots were studied.

Results: Soils were Gleysol and flooded during the rainy season. Most of identified plant species were herbaceous, with Cyperus articulatus and Mimosa pigra as the dominant species. Seven of 8 analyzed plant species exhibited differential co-colonization between AMF and DSE. Repeated sampling for one year under flooding/dry conditions demonstrated that $C$. articulatus and $M$. pigra were mainly associated with DSE and AMF, respectively. A positive correlation between dissolved $\mathrm{O}_{2}$ in the water column and fungal colonization was observed in $C$. articulatus. Glomerales and Archaeosporales were molecularly identified inside roots containing arbuscules of M. pigra.

Conclusions: Findings highlight differential coexistence between AMF and DSE in plant roots; fungal colonization was influenced by flooding/dry conditions in a neotropical wetland; the community of AMF inside arbusculated roots of $M$. pigra includes at least four clades.

Keywords: Arbuscular mycorrhizal fungi, Cyperus articulatus, dark septate endophyte fungi, gleysol, Mimosa pigra, Neotropics.

\section{Resumen}

Antecedentes: Los humedales del neotrópico albergan una alta diversidad fúngica, incluyendo hongos micorrízico arbusculares (HMA) y hongos endófitos septados oscuros (ESO). Se describe la interacción vegetal con HMA y ESO en un humedal de agua dulce.

Hipótesis: La colonización radical diferencial entre HMA y ESO es influenciada por la especie vegetal y por las condiciones abióticas en un humedal de agua dulce.

Especies en estudio: Especies vegetales colonizadas por HMA y por ESO.

Métodos: Fueron analizadas las propiedades del suelo y de la columna de agua, la composición florística y la colonización fúngica radical; se identificó molecularmente la comunidad intrarradical de HMA en una planta.

Resultados: Los suelos Gleysol estuvieron anegados durante la estación lluviosa. La mayoría de las plantas identificadas fueron herbáceas; dominaron Cyperus articulatus y Mimosa pigra. Siete especies vegetales exhibieron co-colonización diferencial por HMA y ESO. Muestreos subsecuentes durante un año bajo condiciones de inundación/secas demostraron que $C$. articulatus y $M$. pigra estuvieron preferentemente colonizadas por hongos ESO y HMA, respectivamente. Una correlación positiva entre el $\mathrm{O}_{2}$ disuelto en la columna de agua y la colonización fúngica fue observada en $C$. articulatus. Glomerales y Archaeosporales fueron molecularmente identificados en el interior de las raíces de $M$. pigra conteniendo arbúsculos.

Conclusiones: Los hallazgos resaltan una coexistencia diferencial entre HMA y ESO en las raíces; la colonización fúngica estuvo influenciada por la inundación/estiaje en el humedal; la comunidad de HMA en el interior de las raíces de M. pigra incluye por lo menos miembros de cuatro clados.
\end{abstract}

Palabras clave: Cyperus articulatus, gleysol, hongo endófito septado oscuro, hongo micorrízico arbuscular, Mimosa pigra, neotrópico.

This is an open access article distributed under the terms of the Creative Commons Attribution License CCBY-NC (4.0) international. https://creativecommons.org/licences/by-nc/4.0/ 
Wetlands are ecosystems with shallow water or saturated soils that possess unique flora and fauna adapted to these unusual environmental conditions. They share common features with both aquatic and terrestrial ecosystems. Wetlands are distinguished from terrestrial systems because soil is often anaerobic. Wetlands vegetation is dominated by trees, shrubs, grasses, and other large plants, in contrast to aquatic systems (van der Valk 2012). It is estimated a global wetland area of 135-1,782 $\times 10^{6}$ ha in the Neotropics (Ramsar Convention Secretariat 2010). High biodiversity and productivity are found in wetlands, providing diverse ecosystem services including fishing, fruits, carbon sequestration, nutrient cycling, and water decontamination, among others. Mexican neotropical region harbors several freshwater wetlands which are flooded during the rainy season.

In nature, most plants are colonized by different groups of fungi; the fungal diversity in the roots of a single plant species growing in a single sampling location has been reported to cover all phyla (Vandenkoornhuyse et al. 2002). The most commonly found fungal groups inhabiting plant roots comprise arbuscular mycorrhizal fungi (AMF) and dark septate endophytes (DSE). AMF [Phylum Mucoromycota, Subphylum Glomeromycotina (Spatafora et al. 2016)] associate with the roots of more than $80 \%$ of vascular plants under a mutualistic interaction denominated arbuscular mycorrhiza (AM) (Smith \& Read 2008). AMF facilitate the assimilation of less mobile nutrients, such as phosphorus (P), through the development of an extended network of hyphae in the soil (Parniske 2008). DSE are mainly Ascomycota, which are capable of colonizing the roots of nearly all plant species (Jumpponen \& Trappe 1998). Knowledge on the roles that the plant root-DSE association plays continues to be very limited. The roles that have been suggested include involvement in enhancing plant survival and performance during periods of stress (Newsham 2011, Mandyam \& Jumpponen 2015). DSE interact with their host plant and/or other endophytes, synthesizing bioactive metabolites, which may play important ecological roles, and may lead to biotechnological applications (Kusari et al. 2012). In a tripartite plant-DSE-AMF interaction, a synergistic relationship has been hypothesized between both fungal groups in relation to $\mathrm{P}$ availability and uptake by plants: DSE increase the $\mathrm{P}$ pool in the rhizosphere, and AMF are responsible for $\mathrm{P}$ transfer to the host (Della Monica et al. 2015).

AMF and DSE exhibit aerobic metabolism and have been reported to co-exist inside the roots of submerged plants in temperate wetlands (Fuchs \& Haselwandter 2004, Sraj-Krzic et al. 2006, Kohout et al. 2012). However, little information is available on the diversity and co-colonization of these two fungal groups and the role that they play in neotropical wetlands, where the water column exhibits a reduction, or even the absence of dissolved oxygen. Particularly in Mexico, there is little information on soil fungi (Sarukhán et al. 2015).

Based on the species endemism of vascular plants and terrestrial vertebrates, the southern half of the country corresponds to the Mesoamerican biodiversity hotspot, which is threatened by habitat destruction and land-use change (My- ers et al. 2000). Considering the role of plants as umbrella species, these areas also function as hotspots for other, less well-studied organisms such as the soil fungi associated with them (Stork \& Habel 2014). Up to 2012, 95 known species of AMF had been reported in Mexico, considered as a high AMF diversity reservoir linked with plant and ecosystem diversity (Montaño et al. 2012). Scarce information exists on the diversity and roles of DSE in neotropical ecosystems (Heredia-Acuña et al. 2014). The aim of the present work was to describe plant root interactions with AMF and DSE in a neotropical freshwater wetland characterized by its hypoxic or anoxic conditions and belonging to a biodiversity hotspot region.

\section{Materials and methods}

Description of the study area. This work was conducted in the seasonally flooded La Mixtequilla neotropical wetland in Veracruz state, Eastern Mexico. La Mixtequilla is located in the Sistema Lagunar Alvarado, which was designated as the Ramsar Site 1355 (Matthews 2013). Blanco River traverses this wetland. The climate is warm, $\mathrm{Aw}_{2}\left(\mathrm{i}^{\prime}\right) \mathrm{w}$ " type, with an average annual temperature of $25.9^{\circ} \mathrm{C}$; in the coldest month, the temperature reaches $22.6^{\circ} \mathrm{C}$, while in the warmest months, it rises to $28.3^{\circ} \mathrm{C}$. Average annual rainfall is $1,531.8 \mathrm{~mm}$, with rain beginning in June and ending in October. Generally, the dry season runs from January to June (Viccon-Pale et al. 2016), with the wetland flooded during the remainder of the year. This region has been negatively impacted by industrial and domestic pollution, by land-use change, as well as by livestock, agriculture, and fishing (Rivera-Becerril et al. 2008, Cejudo-Espinosa et al. 2009, Moreno-Casasola et al. 2009).

Field work. For soil analysis, two sampling stations were established at the eastern and western banks of the Blanco River: Don Rufino (18 31' 57.9" N, 95 57' 35.7" W; 2 m ASL), and El Llanete (18 31' 40.2" N, 95 56' 45.9" W; 2 $\mathrm{m}$ ASL), respectively. Both sites are employed as livestock grasslands, and they exhibit differences in plant communities, particularly, in the abundance of some plant species. During the dry season, five plots $\left(1 \mathrm{~m}^{2}\right.$ each) were randomly established at each pastureland (El Llanete and Don Rufino). Three soil samples from each plot were taken from the top $20 \mathrm{~cm}$ of soil using a spade. Throughout the whole year, considering their high abundance, representative plants from these five plots at each station were collected (roots, shoots, flowers) for identification. Root fungal colonization was estimated once a year in each plant species shown in table 4. In addition, it was carried out repeated sampling for a year in order to monitor fungal colonization in Cyperus articulatus from Don Rufino, and in Mimosa pigra from El Llanete, because these were the dominant species. An aliquot of each root system from the top $20 \mathrm{~cm}$ of soil was stored at $4{ }^{\circ} \mathrm{C}$ to quantify fungal colonization.

For water quality evaluation, two sampling stations were also established at each pastureland, Don Rufino, and El Llanete. During the rainy season, both livestock grasslands 
were flooded. Water depth was determined with a wooden ruler. Temperature and dissolved oxygen concentration in the water column were measured with a Hydrolab DS5 multiparameter instrument (Hach Company, Loveland, CO, USA) one day per month, from September 2011 to September 2012, each hour (36 recordings during $6 \mathrm{~min}$ ) from 11:00 to 17:00 h. Additionally, a water sample was collected every two hours from 11:00 to $17: 00 \mathrm{~h}$ in plastic bottles and stored at $4{ }^{\circ} \mathrm{C}$ for orthophosphate $\left(\mathrm{PO}_{4}{ }^{3-}\right)$ estimation.

Soil and water chemical analyses. Soil samples (1.5 kg) were dried at room temperature and sieved through a $2.0 \mathrm{~mm}$ diameter sieve. Bulk and particle densities were measured using a pycnometer with the paraffin-coated clod method and the undisturbed soil core method, respectively (USDA 2004). Soil porosity was calculated according to USDA (2011). Soil texture was determined following the Gee \& Bauder method (1986), and soil color, according to the Munsell notation. Soil $\mathrm{pH}$ was measured in water with a glass electrode potentiometer (Orion STR 3) at a 1:2.5 ratio (w/v). Soil organic matter (SOM) content was determined employing the wet combustion method (USDA 2004); organic carbon (OC) and total nitrogen $(\mathrm{TN})$ were calculated from these results as follows: $\mathrm{OC}=\mathrm{SOM} / 1.724, \mathrm{TN}=\mathrm{SOM}(0.05)$. The concentration of available $\mathrm{P}$ in soils was determined using the USDA method (2004). Cation-exchange capacity (CEC) was calculated by saturation with ammonium acetate and analysis with EDTA (Jackson 1982), the content of exchangeable cations $\mathrm{Ca}^{2+}$ and $\mathrm{Mg}^{2+}$ by the Versenate method (USDA 2004), and $\mathrm{Na}^{+}$ and $\mathrm{K}^{+}$, by flame photometry (Corning 400). Orthophosphate $\left(\mathrm{PO}_{4}{ }^{3-}\right)$ concentration in water was determined following the 4500-P E ascorbic acid method (APHA-WEF 2005).

Root colonization measurements. Identification of plant species was conducted according to López-Ríos \& Rosas-López (1988) and to Calderón de Rzedowski \& Rzedowski (2001). To estimate fungal colonization, roots from three individual of each plant species were cleared with $10 \% \mathrm{KOH}$ and stained with $0.05 \%$ trypan blue (Phillips \& Hayman 1970) in lactoglycerol. From each root system, 30, 1-cm root segments were placed on a slide with glycerol and observed under a light microscope. The ocurrence of Paris (absence of intercellular hyphae, presence of intracellular hyphal coils) and Arum (intercellular hyphal growth, terminal arbuscules on intracellular hyphal branches) morphotypes of AM was qualitatively recorded (Dickson et al. 2007). Levels of AMF colonization were calculated considering the intensity of mycorrhizal colonization (M \%: hyphae, vesicles, and arbuscules) and the abundance of arbuscules (A \%) in the root system (Trouvelot et al. 1986). This methodology was also applied for estimating root colonization by DSE; the same $30,1-\mathrm{cm}$ root segments that had been previously clarified and stained were evaluated for estimating intensity of colonization ( $\mathrm{C} \%$ : septate hyphae and microsclerotia) and abundance of microsclerotia (MS \%) in the root system.

Molecular identification of arbuscular mycorrhizal fungi. A composited sample of flooded $M$. pigra roots containing arbuscules from El Llanete was washed with tap water, disinfected, and rinsed with sterilized water. Extraction of genomic DNA was carried out following the DNAzol Reagent kit protocol. DNA was resuspended in ultrapure water; its concentration was estimated in a NanoDrop 2000c spectrophotometer (Thermo Scientific, Wilmington, DE, USA). A nested-PCR protocol was applied for amplifying ribosomal sequences of AMF (Krüger et al. 2009). The first PCR mix (25 $\mu$ l total volume) was prepared as follows: buffer $1 \mathrm{X}$ $1.5 \mathrm{mM} \mathrm{MgCl} ; 0.2 \mathrm{mM}$ of each deoxynucleotide triphosphates (dNTP); $0.2 \mu \mathrm{M}$ of each primer (SSUmAf1-2 mix, LSUmAr1-4); 1 U Platinum Taq polymerase (Invitrogen, Brazil), and 10 ng DNA as template. PCR reactions were performed in a MultiGene Thermal Cycler (Model TC9600G; Edison, NJ, USA) with the following parameters: initial denaturation at $94{ }^{\circ} \mathrm{C} / 2 \mathrm{~min} ; 32$ cycles of denaturation at $94{ }^{\circ} \mathrm{C} / 30 \mathrm{~s}$; annealing at $50{ }^{\circ} \mathrm{C} / 30 \mathrm{~s}$; elongation at $72{ }^{\circ} \mathrm{C} / 2 \mathrm{~min}$, and a final elongation at $72{ }^{\circ} \mathrm{C} / 10 \mathrm{~min}$. Amplified fragments were used after a 1:10 dilution in ultrapure water. The second PCR mix (25 $\mu$ l total volume) was prepared using primer mixes SSUmCf1-3 and LSUmBr1-5. The same PCR conditions were employed, except that the annealing temperature was reduced to $48{ }^{\circ} \mathrm{C}$, and that Taq polymerase $(2 \mathrm{U})$ and $\mathrm{MgCl}_{2}(3 \mathrm{mM})$ were doubled. Products were visualized by electrophoresis and stained with ethidium bromide. Amplification bands of $\sim 1.5 \mathrm{~kb}$ for SSUmCf/LSUmBr were cut from the gel and DNA was extracted with the QIAquick Gel Extraction kit (Qiagen, Oregon, USA). PCR bands were ligated to pGEM-T vector (Promega, Madison, WI, USA) and used to transform competent Escherichia coli JM-109 cells (Promega). Plasmid minipreps were conducted (QIAprep Spin Miniprep Kit), and the clones were sequenced with the aid of an ABI Prism 3100 Automated Sequencer (LANGEBIO, CINVESTAV-Irapuato, Mexico). Sequencing was unidirectional and conducted using the T7 primer. The Glomeromycotina origin of the sequences was confirmed by BLAST-N comparison with sequences deposited in GenBank (NCBI) and Glomeromycotina dedicated database Maarj $A M$ (Öpik et al. 2010). Multiple alignment was performed using MUSCLE (Edgar 2004), and the alignment was manually optimized with Jalview software (Waterhouse et al. 2009). The evolutionary history was inferred by using the Maximum Likelihood method based on the Kimura 2-parameter model (Kimura 1980). The tree with the highest log likelihood $(-3,947.04)$ is shown. The percentage of trees in which the associated taxa clustered together is shown next to the branches. The tree was drawn to scale, with branch lengths measured in the number of substitutions per site. The analysis involved 54 nucleotide sequences. All positions with less than $95 \%$ site coverage were eliminated. That is, fewer than $5 \%$ alignment gaps, missing data, and ambiguous bases were allowed at any position. There was a total of 453 positions in the final dataset. Evolutionary analyses were conducted in MEGA7 (Kumar et al. 2016).

Statistical analyses. Data were checked for normal distribution with the Shapiro-Wilk test. One-way analysis of variance (ANOVA) at a significance level of 0.05 was performed 
on fungal colonization variables. Whenever there were significant differences, Tukey tests were conducted to determine differences among homogeneous groups of means $(p<0.05)$. Comparisons for each soil property between both pasturelands, as well as comparisons of AMF/DSE colonization in plant species, were subjected to a Student's $t$-test. Pearson correlations were carried out between AMF and DSE colonization in $M$. pigra and $C$. articulatus, as well as between properties of water and fungal colonization. These analyses were computed using Origin 8.6 software.

\section{Results}

Soil and water column properties in pasturelands. Concerning soil properties, bulk density was similar in both pasturelands under study; particle density and porosity were significantly higher $(p<0.05)$ in El Llanete than in Don Rufino (Table 1). Soils from both pasturelands were dominated by clay particles ( 60 and $72 \%$ ), with a clay texture; no significant differences were observed between pasturelands when comparing concentrations of sand, silt, and clay in soils. Both soils were dark gray $(2.5 \mathrm{Y} 4 / 1)$ when dry, and

Table 1. Physical and chemical properties in soils of the pasturelands Don Rufino and El Llanete at La Mixtequilla wetland (mean $\pm \mathrm{SE}$; $n=15$, except for sand, silt, and clay, where $n=5$ ).

\begin{tabular}{|c|c|c|}
\hline & Don Rufino & El Llanete \\
\hline \multicolumn{3}{|l|}{ Physical properties } \\
\hline Bulk density $\left(\mathrm{g} \mathrm{cm}^{-3}\right)$ & $1.2 \pm 0.01$ & $1.2 \pm 0.02$ \\
\hline Particle density $\left(\mathrm{g} \mathrm{cm}^{-3}\right)$ & $2.2 \pm 0.04 *$ & $2.3 \pm 0.01^{*}$ \\
\hline Porosity (\%) & $46.1 \pm 0.89 *$ & $49.1 \pm 0.77^{*}$ \\
\hline Sand $(\%)$ & $15.5 \pm 2.10$ & $11.5 \pm 0.82$ \\
\hline Silt (\%) & $12.1 \pm 1.76$ & $28.7 \pm 11.70$ \\
\hline Clay $(\%)$ & $72.4 \pm 0.93$ & $59.8 \pm 12.13$ \\
\hline Texture & Clay & Clay \\
\hline Color (dry) & $2.5 \mathrm{Y} 4 / 1$ & $2.5 \mathrm{Y} 4 / 1$ \\
\hline Color (wet) & Gley $13 / \mathrm{N}$ & Gley $13 / \mathrm{N}$ \\
\hline \multicolumn{3}{|l|}{ Chemical properties } \\
\hline $\mathrm{pH}$ & $6.5 \pm 0.04$ & $6.3 \pm 0.15$ \\
\hline Organic matter $(\%)$ & $6.2 \pm 0.48$ & $6.9 \pm 0.49$ \\
\hline Organic carbon $(\%)$ & $3.6 \pm 0.28$ & $4.0 \pm 0.28$ \\
\hline Total nitrogen $(\%)$ & $0.3 \pm 0.02$ & $0.3 \pm 0.02$ \\
\hline Available phosphorus $\left(\mathrm{mg} \mathrm{kg}^{-1}\right)$ & $9.9 \pm 0.45^{*}$ & $17.0 \pm 2.68 *$ \\
\hline $\begin{array}{l}\text { Cation exchange capacity } \\
\left(\text { meq } 100 \mathrm{~g}^{-1}\right)\end{array}$ & $40.3 \pm 0.51$ & $39.1 \pm 0.72$ \\
\hline $\mathrm{Ca}^{2+}\left(\right.$ meq $\left.100 \mathrm{~g}^{-1}\right)$ & $40.0 \pm 1.13$ & $37.0 \pm 1.56$ \\
\hline $\mathrm{Na}^{+}\left(\right.$meq $\left.100 \mathrm{~g}^{-1}\right)$ & $6.3 \pm 0.31 *$ & $11.1 \pm 1.20^{*}$ \\
\hline $\mathrm{Mg}^{2+}\left(\right.$ meq $\left.100 \mathrm{~g}^{-1}\right)$ & $3.7 \pm 0.64 *$ & $7.4 \pm 1.53^{*}$ \\
\hline $\mathrm{K}^{+}\left(\right.$meq $\left.100 \mathrm{~g}^{-1}\right)$ & $2.6 \pm 0.19 *$ & $3.5 \pm 0.31 *$ \\
\hline
\end{tabular}

Asterisks indicate significant differences $(p<0.05)$ between both pasturelands, following a Student's $t$-test. very dark gray (Gley1 3/N) when wet. Among chemical properties, there were no statistically significant differences between pasturelands on the $\mathrm{pH}$, organic matter content, organic carbon, total nitrogen and CEC. The CEC complex was dominated by $\mathrm{Ca}^{2+}$, which did not show significant differences between pasturelands; $\mathrm{Na}^{+}, \mathrm{Mg}^{2+}$, and $\mathrm{K}^{+}$were significantly higher $(p<0.05)$ at El Llanete. The available $\mathrm{P}$ in soil, measured as orthophosphate, was significantly higher $(p<0.05)$ at El Llanete than at Don Rufino by nearly two-fold (Table 1).

During the flood season, the water column was shallow in both pasturelands $(25.1 \pm 10.5 \mathrm{~cm})$. The highest water temperatures were recorded in September at Don Rufino $\left(34.5^{\circ} \mathrm{C}\right)$ and July at El Llanete $\left(30.6{ }^{\circ} \mathrm{C}\right)$; lowest temperatures were registered during winter at both sites (Table 2). Higher levels of dissolved oxygen were found during February at Don Rufino $\left(5.5 \mathrm{mg} \mathrm{L}^{-1}\right)$ and in October at El Llanete (4.3 $\left.\mathrm{mg} \mathrm{L}^{-1}\right)$. Orthophosphate in water was higher in September at Don Rufino $\left(0.3 \mathrm{mg} \mathrm{L}^{-1}\right)$ and in December at El Llanete $\left(0.3 \mathrm{mg} \mathrm{L}^{-1}\right)$.

Floristic composition. In both pasturelands, the plant community known as "popal" was predominant with majority of herbaceous native species from Mexico (Table 3). At the Don Rufino pastureland, 18 plant species belonging to 12 families were identified; some of these, such as Thalia geniculata, Cyperus articulatus, and Mimosa pigra, are adapted to both flood and dry conditions; others (Salvinia minima and Eichhornia crassipes) exhibit aquatic habits. During the flood season, the most abundant plant species were $C$. articulatus, Echinodorus paniculatus, and $T$. geniculata, while during the dry season, the latter predominated. In the El Llanete pastureland, 23 plant species belonging to 14 families were identified; some of these, such as T. geniculata and M. pig$r a$, tolerate both flood and dry seasons; others (Marsilea crotophora, S. minima, and Nymphaea ampla) demonstrate aquatic habits. During the whole year, including flood and dry seasons, the most abundant plant species was $M$. pigra, followed by $T$. geniculata.

Fungal colonization of roots. As a first insight into the status of AMF and DSE interactions in the wetland, six plant species from both pasturelands were sampled during the flood or dry seasons and analyzed for the presence of these fungi (Table 4). Echinodorus paniculatus did not exhibit any fungal colonization, while five plant species were co-colonized by both fungal groups at different levels. Concerning AMF, $S$. herbacea during fructification showed the highest percentage of root colonization $(\mathrm{M}=53 \%)$, as well as the highest abundance of arbuscules in the whole root system $(\mathrm{A}=3.5 \%)$. Vesicles were present in all plant species, with $S$. herbacea exhibiting the highest abundance. Arum and Paris-type morphologies of AM were visualized in all plant roots, but the former predominated. Fimbristylis spadicea demonstrated highest intensity of DSE root colonization $(\mathrm{C}=16 \%)$, while in the remaining plants, this was $\leq 9 \%$. The abundance of microsclerotia in the whole root system (MS) was $\leq 1 \%$ in all cases. In $S$. herbacea, the percentage 
Table 2. Water column properties during the flood season of the Don Rufino (DR) and El Llanete (EL) pasturelands at La Mixtequilla wetland (mean \pm SE; $n=252$, except for orthophosphate concentration, where $n=4$ ).

\begin{tabular}{|c|c|c|c|c|c|c|}
\hline \multirow[b]{2}{*}{$\begin{array}{l}\text { Sampling date } \\
\text { (month/year) }\end{array}$} & \multicolumn{2}{|c|}{$\begin{array}{l}\text { Temperature } \\
\left({ }^{\circ} \mathbf{C}\right)\end{array}$} & \multicolumn{2}{|c|}{$\begin{array}{c}\mathrm{O}_{2} \text { concentration } \\
\left(\mathrm{mg} \mathrm{L}^{-1}\right)\end{array}$} & \multicolumn{2}{|c|}{$\begin{array}{l}\text { Orthophosphate concentration } \\
\qquad\left(\mathrm{mg} \mathrm{L}^{-1}\right)\end{array}$} \\
\hline & DR & EL & DR & EL & DR & EL \\
\hline 09/11 & $34.5 \pm 1.7$ & $30.1 \pm 0.4$ & $2.6 \pm 0.7$ & $0.5 \pm 0.1$ & $0.312 \pm 0.22$ & $0.196 \pm 0.09$ \\
\hline $10 / 11$ & $29.9 \pm 1.5$ & $27.5 \pm 0.5$ & $2.3 \pm 0.4$ & $4.3 \pm 0.2$ & $0.145 \pm 0.01$ & $0.028 \pm 0.02$ \\
\hline $11 / 11$ & $28.1 \pm 1.3$ & $28.0 \pm 0.5$ & $3.3 \pm 0.4$ & $2.4 \pm 0.5$ & $0.033 \pm 0.06$ & $0.050 \pm 0.02$ \\
\hline $12 / 11$ & $27.7 \pm 1.0$ & $24.7 \pm 0.3$ & $3.0 \pm 0.7$ & $1.7 \pm 0.3$ & $0.104 \pm 0.04$ & $0.335 \pm 0.28$ \\
\hline $01 / 12$ & $24.9 \pm 1.5$ & $21.4 \pm 0.2$ & $3.3 \pm 0.6$ & $1.2 \pm 0.4$ & $0.002 \pm 0.004$ & $0.044 \pm 0.04$ \\
\hline $02 / 12$ & $21.7 \pm 1.8$ & $25.3 \pm 1.4$ & $5.5 \pm 1.1$ & $0.7 \pm 0.3$ & $0.117 \pm 0.06$ & $0.042 \pm 0.03$ \\
\hline $04 / 12$ & - & - & - & - & - & - \\
\hline $06 / 12$ & - & - & - & - & - & - \\
\hline $07 / 12$ & $30.9 \pm 2.3$ & $30.6 \pm 1.2$ & $1.2 \pm 0.5$ & $1.5 \pm 0.7$ & $0.179 \pm 0.09$ & $0.108 \pm 0.01$ \\
\hline 09/12 & $30.6 \pm 1.1$ & $29.7 \pm 1.0$ & $0.4 \pm 0.2$ & $0.6 \pm 0.2$ & $0.163 \pm 0.01$ & $0.133 \pm 0.03$ \\
\hline
\end{tabular}

-, Absence of water column during the dry season.

Table 3. Representative plant species in two pasturelands at La Mixtequilla wetland.

\begin{tabular}{|c|c|c|}
\hline Family & Plant species & Observations \\
\hline \multicolumn{3}{|c|}{ Don Rufino pastureland } \\
\hline \multicolumn{3}{|c|}{ POLYPODIOPHYTA } \\
\hline Salvianiaceae & Salvinia minima Baker & Aquatic fern, native \\
\hline \multicolumn{3}{|c|}{ MAGNOLIOPHYTA } \\
\hline \multicolumn{3}{|c|}{ LILIOPSIDA } \\
\hline Alismataceae & Echinodorus paniculatus Micheli & Herbaceous, native \\
\hline Cyperaceae & Cyperus articulatus L. & Perennial, herbaceous, native \\
\hline \multirow[t]{3}{*}{ Poaceae } & Echinochloa crus-pavonis (Kunth) Schult. & Perennial, herbaceous, native \\
\hline & Hymenachne amplexicaulis (Rudge) Nees & Perennial, herbaceous, native \\
\hline & Paspalum repens P.J. Bergius & Perennial, herbaceous, native \\
\hline Pontederiaceae & Eichhornia crassipes (Mart.) Solms & Aquatic, herbaceous, exotic \\
\hline \multicolumn{3}{|c|}{ MAGNOLIOPSIDA } \\
\hline Bignoniaceae & Crescentia cujete $\mathrm{L}$. & Tree, native \\
\hline \multirow[t]{2}{*}{ Boraginaceae } & Heliotropium indicum $\mathrm{L}$. & Herbaceous, native \\
\hline & H. macrostachyum (DC.) Hemsl. & Herbaceous, native \\
\hline Euphorbiaceae & Chamaesyce prostrata (Aiton) Small & Herbaceous, native \\
\hline \multirow[t]{4}{*}{ Fabaceae } & Lonchocarpus hondurensis Benth. & Tree, native \\
\hline & Pithecellobium dulce (Roxb.) Benth. & Tree, native \\
\hline & Mimosa pigra $\mathrm{L}$. & Shrub, native \\
\hline & Neptunia natans W. Treob. & Perennial, herbaceous, native \\
\hline Maranthaceae & Thalia geniculata $\mathrm{L}$. & Aquatic, herbaceous, native \\
\hline Solanaceae & Solanum rostratum Dunal & Invasive, herbaceous, native \\
\hline Verbenaceae & Phyla nodiflora (L.) Greene & Herbaceous, native \\
\hline
\end{tabular}

El Llanete pastureland

POLYPODIOPHYTA

Marsileaceae 
Table 3. Continue.

\begin{tabular}{|c|c|c|}
\hline Family & Plant species & Observations \\
\hline & Salvinia minima Baker & Aquatic fern, native \\
\hline \multicolumn{3}{|c|}{ MAGNOLIOPHYTA } \\
\hline \multicolumn{3}{|l|}{ LILIOPSIDA } \\
\hline \multirow[t]{3}{*}{ Cyperaceae } & Cladium jamaicense Crantz & Perennial, herbaceous, native \\
\hline & Cyperus articulatus L. & Perennial, herbaceous, native \\
\hline & Fimbristylis spadicea (L.) Vahl & Perennial, herbaceous, native \\
\hline Nymphaceae & Nymphaea ampla DC. & Perennial, herbaceous, native \\
\hline \multirow[t]{2}{*}{ Poaceae } & Paspalum fasciculatum Willd. ex Flüggé & Perennial, herbaceous, native \\
\hline & Paspalum sp. & Perennial, herbaceous \\
\hline \multicolumn{3}{|c|}{ MAGNOLIOPSIDA } \\
\hline \multirow[t]{2}{*}{ Acanthaceae } & Ruellia geminiflora Kunth & Herbaceous, native \\
\hline & R. paniculata $\mathrm{L}$. & Herbaceous, native \\
\hline Alismataceae & Echinodorus paniculatus Micheli & Herbaceous, native \\
\hline Arecaceae & Sabal mexicana Mart. & Arborescent, native \\
\hline Asteraceae & Erigeron aff. heteromorphus & Herbaceous, native \\
\hline Euphorbiaceae & Euphorbia marginata Pursh & Herbaceous, exotic \\
\hline \multirow[t]{4}{*}{ Fabaceae } & Crotalaria pallida Aiton & Herbaceous, native \\
\hline & Mimosa pigra $\mathrm{L}$. & Shrub, native \\
\hline & Neptunia plena (L.) Benth. & Seedling, native \\
\hline & Sesbania herbacea (Mill.) McVaugh & Herbaceous, native \\
\hline Lythraceae & Cuphea spp. & Herbaceous, native \\
\hline Maranthaceae & Thalia geniculata $\mathrm{L}$. & Seedling, native \\
\hline \multirow[t]{2}{*}{ Onagraceae } & Ludwigia helminthorrhiza (Mart.) H. Hara & Prostrate, herbaceous, native \\
\hline & L. leptocarpa (Nutt.) H. Hara & Aquatic, herbaceous, native \\
\hline Solanaceae & Solanum lanceifolium Jacq. & Shrub, native \\
\hline
\end{tabular}

All of the plant species follow the nomenclature of vascular flora by MEXU Herbarium (www.ib.unam.mx/botanica/herbario/), and W3 Tropicos Missouri Botanical Garden (www.tropicos.org)

Table 4. Root colonization by arbuscular mycorrhizal fungi and dark septate endophytes in plants established at two pasturelands of La Mixtequilla wetland (mean $\pm \mathrm{SE} ; n=3$ ). Evaluation was carried out once in a year.

\begin{tabular}{|c|c|c|c|c|c|}
\hline \multirow[b]{2}{*}{ Plant species } & \multicolumn{3}{|c|}{ Arbuscular mycorrhizal fungi } & \multicolumn{2}{|c|}{ Dark septate endophytes } \\
\hline & M (\%) & $\mathbf{A}(\%)$ & $\mathbf{V}$ & $\mathrm{C}(\%)$ & MS (\%) \\
\hline \multicolumn{6}{|l|}{ Don Rufino pastureland } \\
\hline Echinochloa cruspavonis ${ }^{\mathrm{b}}$ & $7.7 \pm 4.7$ & $0.1 \pm 0.1$ & + & $3.9 \pm 2.2$ & $0.5 \pm 0.3$ \\
\hline Echinodorus paniculatus ${ }^{\mathrm{b}}$ & 0 & 0 & - & 0 & 0 \\
\hline \multicolumn{6}{|l|}{ EI Llanete pastureland } \\
\hline Sesbania herbacea (flowering period) & $29.9 \pm 4.0^{*}$ & $2.6 \pm 1.0$ & + & $4.5 \pm 1.9^{*}$ & $0.6 \pm 0.4$ \\
\hline Sesbania herbacea ${ }^{\text {a }}$ (fructification period) & $53.4 \pm 1.5^{*}$ & $3.5 \pm 1.2$ & + & $8.7 \pm 4.1^{*}$ & $0.6 \pm 0.4$ \\
\hline Ruellia geminiflora ${ }^{\mathrm{a}}$ & $17.4 \pm 7.5$ & $1.7 \pm 1.0$ & + & $7.1 \pm 2.9$ & $0.2 \pm 0.2$ \\
\hline Fimbristylis spadicea ${ }^{\mathrm{a}}$ & $3.8 \pm 2.8$ & 0 & + & $16.0 \pm 4.3$ & $0.6 \pm 0.1$ \\
\hline Thalia geniculata $^{\mathrm{b}}$ & $5.3 \pm 1.8$ & 0 & + & $4.5 \pm 1.5$ & $0.3 \pm 0.2$ \\
\hline
\end{tabular}

$\mathrm{M}$, intensity of mycorrhizal colonization in the root system; A, abundance of arbuscules in the root system; V, vesicles (+, present; -, absent); C, intensity of colonization by DSE in the root system; MS, abundance of microsclerotia in the root system; ', unflooded plants; b, flooded plants; asterisks indicate significant differences $(p<0.05)$ between M \% and C \% in S. herbacea, following a Student's $t$-test 
of root colonization by AMF (M) was significantly higher $(p<0.05)$ than that of DSE (C). Finally, S. herbacea in fructification attained highest levels of root colonization by both groups of fungi $(\mathrm{M}+\mathrm{C}=62 \%)$.

Repeated monitoring of fungal colonization in the roots of two plant species. In C. articulatus roots, AMF colonization was present at each sampling time (Figure 1). Only hyphae and vesicles were detected, and arbuscules were absent; Paris-type morphology predominated, as judged by presence of intracellular hyphal coils and absence of intercellular hy-

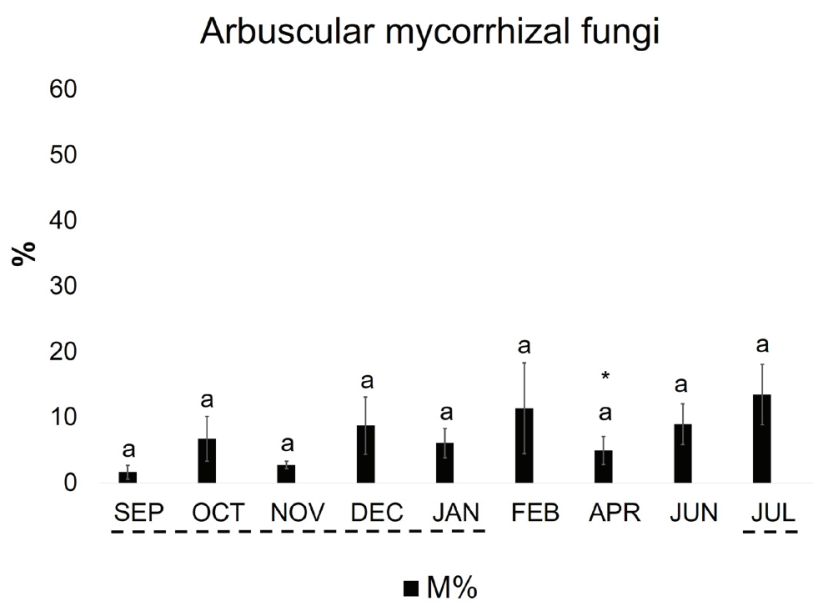

Dark septate endophytes

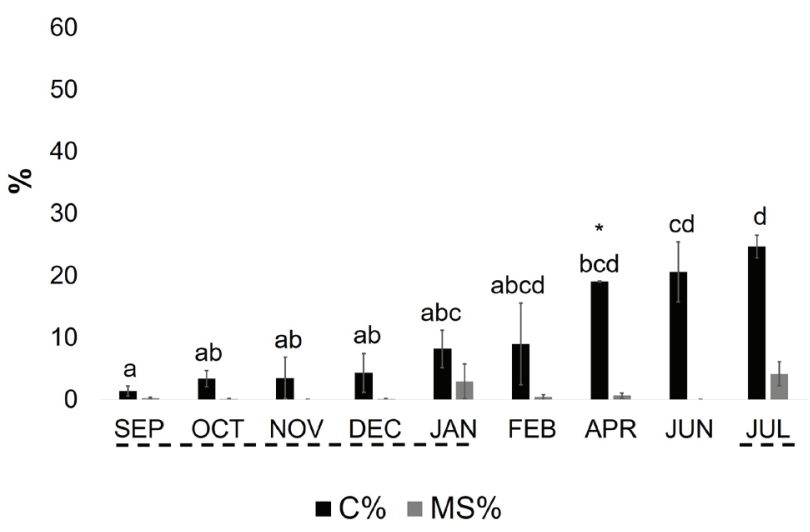

Figure 1. Root colonization by arbuscular mycorrhizal fungi and dark septate endophytes in Cyperus articulatus established in the pastureland Don Rufino at La Mixtequilla wetland (mean \pm SE; $n=3$ ). Evaluation was carried out nine times in a year. M, intensity of mycorrhizal colonization in the root system; $\mathrm{C}$, intensity of colonization by DSE in the root system; MS, abundance of microsclerotia in the root system; broken lines indicate plants under flooding conditions; asterisks indicate significant differences $(p<0.05)$ between $\mathrm{M} \%$ and $\mathrm{C} \%$ (Student's $t$-test); different letter on the bars indicate differences among homogeneous groups of means $(p<0.05)$, following an ANOVA. phae. The highest intensity of root colonization $(\mathrm{M}=13.5 \%)$ was observed in July, but without significant differences among the sampling months. DSE colonization was also present throughout the year. The percentage of root colonization (C) was $<10 \%$ in flooded plants, increasing during the dry season, demonstrating the significant, highest peak $(p<0.05)$ in July $2012(\mathrm{C}=25 \%)$ when the second flood period started. Highest abundance of microsclerotia in the whole root system (MS) was also observed in July 2012 (MS $=4 \%$ ), but without differences among sampling months. During the dry season, the percentage of root colonization by DSE was always higher than that of AMF, particularly in April, with significant differences $(p<0.05)$. In July 2012, C. articulatus attained highest levels of colonization by both groups of fungi in the whole root system $(\mathrm{M}+\mathrm{C}=38.2 \%)$. A Pearson correlation $(r)$ considering all data of intensity of root colonization by AMF (M) and DSE (C) in C. articulatus, showed a significant correlation $(r=0.62 ; p<0.05)$ between both fungal groups.

AMF and DSE colonized $M$. pigra roots during the whole annual cycle (Figure 2). Concerning AMF, intensity of root colonization $(\mathrm{M})$ was significantly highest $(p<0.05)$ in February 2012 during the flooded season $(61 \%)$. The highest abundance of arbuscules in the whole root system (A) was observed under dry conditions. During nearly all the year, few vesicles were present in the roots; Arum and Paris-type morphologies were present. Concerning DSE, the highest percentage of root colonization (C) was observed in April (11\%), without differences among sampling months; abundance of microsclerotia in the whole root system (MS) was $<1 \%$. In February 2012, M. pigra attained highest levels of colonization by both groups of fungi in the whole root system $(\mathrm{M}+\mathrm{C}=62 \%)$. At 6 sampling times, colonization by AMF was significantly higher $(p<0.05)$ than that of DSE. There was no correlation between intensity of root colonization by AMF (M) and DSE (C) in M. pigra, following a Pearson test.

Relations between fungal root colonization and water column properties. Significant correlations $(p<0.05)$ were observed between fungal colonization parameters and water column properties (Table 5). In C. articulatus established in Don Rufino pastureland, a negative correlation between $\mathrm{M}$ or $\mathrm{C}$ and temperature was observed. In addition, higher concentrations of dissolved oxygen in the water column favored root colonization by AMF (M) and DSE (C). A negative correlation between $\mathrm{C}$ and the concentration of orthophosphates was also identified. In M. pigra established in El Llanete, negative correlations were identified between $\mathrm{C}$ or MS and temperature; dissolved oxygen was negatively correlated with $\mathrm{M}$ and A. Finally, higher orthophosphate concentrations in the water column increased the abundance of arbuscules (A) in the whole root system.

Molecular identification of AMF in Mimosa pigra roots. Because $M$. pigra was highly colonized by Glomeromycotina, identification of AMF inside roots containing arbuscules was addressed by a molecular approach targeting fungal rDNA sequences (SSU-ITS-LSU) (Krüger et al. 2009). The size of 


\section{Arbuscular mycorrhizal fungi}

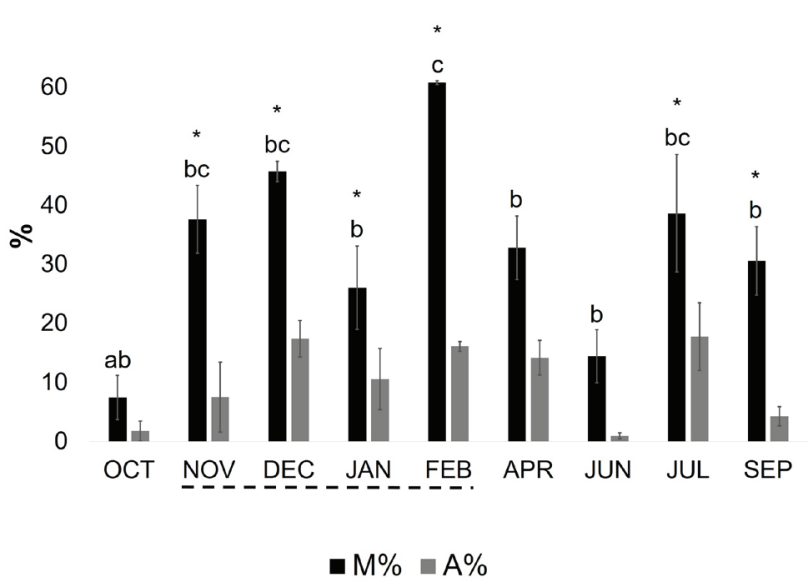

\section{Dark septate endophytes}

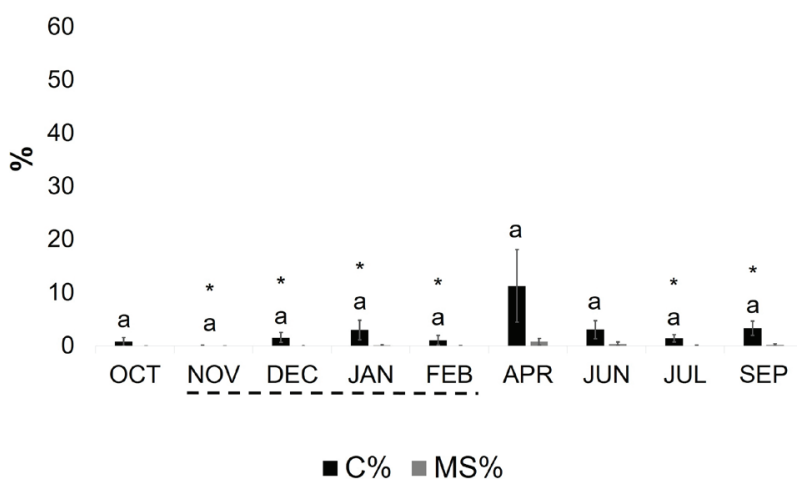

Figure 2. Root colonization by arbuscular mycorrhizal fungi and dark septate endophytes in Mimosa pigra established in the pastureland El Llanete at La Mixtequilla wetland (mean $\pm \mathrm{SE} ; n=3$ ). Evaluation was carried out nine times in a year. $\mathrm{M}$, intensity of mycorrhizal colonization in the root system; A, abundance of arbuscules in the root system; $\mathrm{C}$, intensity of colonization by DSE in the root system; MS, abundance of microsclerotia in the root system; broken lines indicate plants under flooding conditions; asterisks indicate significant differences $(p<0.05)$ between M \% and C \% (Student's $t$-test); different letter on the bars indicate differences among homogeneous groups of means $(p<0.05)$, following an ANOVA.

the final amplified fragments was $\sim 1.5 \mathrm{~kb}$, corresponding to that expected for Glomeromycotina species. These amplicons were employed to construct a SSU-ITS-LSU rDNA library. Fifty recombinant clones of $E$. coli were randomly selected and subcultured; isolated plasmid DNA was digested with EcoRI enzyme in order to corroborate the exact size of inserts; 38 positive samples were sequenced, but only 30 of these exhibited good sequence quality. No chimeric amplicon sequences were detected, and all of the sequences obtained showed a high degree of similarity to Glomeromycotina SSU-ITS-LSU rDNA sequences. All the 30 sequences were submitted to the GenBank database at NCBI (accession num- bers from MK418498 to MK418527). Phylogenetic analyses revealed four monophyletic ribotypes (Figure 3); three of these belonged to the Order Glomerales and one, to Archaeosporales. Concerning Glomerales, 11 of the sequences were grouped with Rhizophagus irregularis/Rh. proliferum, and seven sequences showed affinity with Rhizophagus diaphanum; a group of two sequences were related to Glomus. Estimates of evolutionary divergence between representative sequences of clades observed in the tree confirmed these ribotypes of Glomerales (Table 6). Finally, a group of ten sequences were included in the Order Archaeosporales and were closely related with Archaeospora.

\section{Discussion}

Soil and water properties in pasturelands. Soils from both pasturelands in the La Mixtequilla wetland showed typical characteristics of Gleysols, such as clay texture and saturation with groundwater for long periods, which develop a typical gleyic color pattern and favor a prolonged $\mathrm{O}_{2}$-deficit phenomenon (Driessen et al. 2001). The significantly higher concentrations of available $\mathrm{P}, \mathrm{Na}^{+}, \mathrm{Mg}^{2+}$, and $\mathrm{K}^{+}$at El Llanete in comparison with the Don Rufino pastureland could be attributed to the different strategies of soil management utilized at these sites (agricultural and/or livestock breeding), as well as to biological activity. Driessen et al. (2001) state that Gleysols in depressions or lowlands possess higher organic matter, CEC, $\mathrm{P}$, and $\mathrm{K}^{+}$than adjacent upland soils; at El Llanete, the flooding season is normally longer than at Don Rufino (Rivera-Becerril et al. 2008), which can influence a higher transport of nutrients from uplands via the Blanco River. River nutrient contribution into the floodplain constitutes an elemental process for floodplain production (Junk et al. 1989). Fertility is also favored by fine soil texture and slow rate of organic matter decomposition (Driessen et al. 2001). Flatlands, temperate to warm temperatures, proliferation of plant cover, and its contribution to high levels of autochthonous organic matter, comprise the causes for very low levels of dissolved oxygen in the water columns of both pasturelands. In general, moisture, temperature seasonality, soil fertility, and/or substrate availability control wetland microbial processes (Gutknecht et al. 2006).

Floristic composition and fungal colonization in roots. Gleysols are covered with swamp vegetation and are normally used for extensive grazing (Driessen et al. 2001) of livestock, as occurs at La Mixtequilla. The "popal" plant community is normally present in the neotropical region of the Atlantic coast of Mexico (Rzedowski 1986). In both pasturelands, most plant species belonged to Magnoliopsida, and were herbaceous, consistently with a report from other neotropical wetland (Moreno-Casasola et al. 2009). Three exotic plant species (E. crassipes, E. marginata, and C. pallida) were detected; the free-floating $E$. crassipes is known as one of the worst macrophyte invaders (Thomaz et al. 2015); in addition to its presence in Don Rufino pastureland, large areas of the Blanco River were covered by this plant species. M. pigra, 
Table 5. Pearson correlation ( $r$ ) between water column properties and fungal colonization in Cyperus articulatus and Mimosa pigra established at La Mixtequilla wetland.

\begin{tabular}{|c|c|c|c|c|}
\hline \multirow[b]{2}{*}{ Plant species } & \multicolumn{2}{|c|}{ Arbuscular mycorrhizal fungi } & \multicolumn{2}{|c|}{ Dark septate endophytes } \\
\hline & $\mathbf{M}(r)$ & $\mathbf{A}(r)$ & $\mathrm{C}(r)$ & MS $(r)$ \\
\hline \multicolumn{5}{|l|}{ Cyperus articulatus } \\
\hline Temperature $\left({ }^{\circ} \mathrm{C}\right)$ & $-0.790^{*}$ & - & $-0.951^{*}$ & -0.359 \\
\hline $\mathrm{O}_{2}$ concentration $\left(\mathrm{mg} \mathrm{L}^{-1}\right)$ & $0.641^{*}$ & - & $0.785^{*}$ & 0.106 \\
\hline $\mathrm{PO}_{4}^{3-}$ concentration $\left(\mathrm{mg} \mathrm{L}^{-1}\right)$ & -0.304 & - & $-0.607 *$ & -0.491 \\
\hline \multicolumn{5}{|l|}{ Mimosa pigra } \\
\hline Temperature $\left({ }^{\circ} \mathrm{C}\right)$ & -0.121 & -0.473 & $-0.977 *$ & $-0.844 *$ \\
\hline $\mathrm{O}_{2}$ concentration $\left(\mathrm{mg} \mathrm{L}^{-1}\right)$ & $-0.817^{*}$ & $-0.864^{*}$ & -0.469 & -0.486 \\
\hline $\mathrm{PO}_{4}{ }^{3-}$ concentration $\left(\mathrm{mg} \mathrm{L}^{-1}\right)$ & 0.320 & $0.616^{*}$ & 0.147 & -0.306 \\
\hline
\end{tabular}

$\mathrm{M}$, intensity of mycorrhizal colonization in the root system; A, abundance of arbuscules in the root system; C, intensity of colonization by DSE in the root system; MS, abundance of microsclerotia in the root system. Asterisks indicate significant correlations $(p<0.05)$

native to the tropics, is a well-recognized invasive plant in Southeast Asia and Australia (Lonsdale 1993). At La Mixtequilla, M. pigra is adapted to both flooded and dry conditions throughout the year; local people normally attempt to eliminate it in order to avoid the perturbation of agricultural practices, livestock breeding, and fishing.

Seven plant species (C. articulatus, E. cruspavonis, $M$. pigra, F. spadicea, $R$. geminiflora, $S$. herbacea, and $T$. geniculata) showed a differential co-colonization between AMF and DSE in roots, either under dry or flooded conditions, as reported for other wetlands (Fuchs \& Haselwandter 2004, Weishampel \& Bedford 2006, de Marins et al. 2009, Sudová et al. 2011). Flooded M. pigra showed the highest abundance of arbuscules, indicating that this symbiosis is functional under flooded conditions at low levels of dissolved $\mathrm{O}_{2}$ (see later). Weishampel \& Bedford (2006) consider that Magnoliopsida exhibit more affinity for AMF than DSE, as observed in three plant species analyzed in this work (M. pigra, $R$. geminiflora and $S$. herbacea).

Repeated monitoring of fungal colonization in roots from two plant species. Cyperus articulatus, a native plant from Mexico, is well adapted to tropical wetlands, where is used as forage (Olivares et al. 2002), as observed at the Don Rufino pastureland. This plant species exhibited low levels (up to $13.5 \%$ ) of AMF colonization, but only hyphae and vesicles were present in roots. Members of Cyperaceae typically show low mycotrophy; their mycorrhizal status could be influenced strongly by environmental conditions such as flooding/dry periods (Muthukumar et al. 2004). The lack of arbuscules has been previously reported in cultivated C. rotundus (Muthukumar et al. 1997) or established in a tropical ecosystem (Muthukumar \& Udaiyan 2002). In contrast, high levels of DSE root colonization indicate that these could play a more relevant role in this sedge. Low root colonization by DSE during the flooded season $(<10 \%)$, in comparison with the higher levels observed during the beginning/ending of the dry period (19-25\%), could suggest that DSE are sensitive to low oxygen concentrations in the water column. In April, during the dry season, a four-fold reduction in colonization by $\mathrm{AMF}$, in contrast with increased colonization by DSE, is probably a consequence of fungal competition for resources during the grazing time (García et al. 2012), as was observed for the grass species Bouteloua gracilis (Medina-Roldán et al. 2008). In this study, a significant correlation was observed between root colonization by AMF and DSE during the annual cycle in C. articulatus. As previously reported for some plant species (Ruotsalainen et al. 2002), this positive correlation might indicate a synergism between both groups of fungi.

Table 6. Estimates of evolutionary divergence between representative ribotypes observed in the phylogenetic tree representing SSU-ITS-LSU rDNA sequences of Glomerales colonizing Mimosa pigra flooded roots. The number of base substitutions per site between sequences are shown. Analyses were conducted using the Maximum Composite Likelihood model and it involved five nucleotides sequences. All positions containing gaps and missing data were eliminated. There was a total of 517 positions in the final dataset. Best hits were following NCBI or Maarj $A M$ databases.

\begin{tabular}{lllll}
\hline Sequence & Distance & Max identity (\%) & Best hit & Propose name \\
\hline MK418527/1-555 & & 96.3 & AY744275 & Rhizophagus \\
MK418515/1-561 & 0.038 & 99 & HG969372 & Rhizophagus \\
MK418522/1-551 & 0.2110 .19 & 97 & AJ972463 & Rhizophagus \\
MK418523/1-551 & 0.1830 .1630 .028 & 97 & AM972463 & Rhizophagus \\
MK418519/1-566 & 0.3030 .2910 .2880 .275 & 94 & AM384981 & Glomus \\
\hline
\end{tabular}




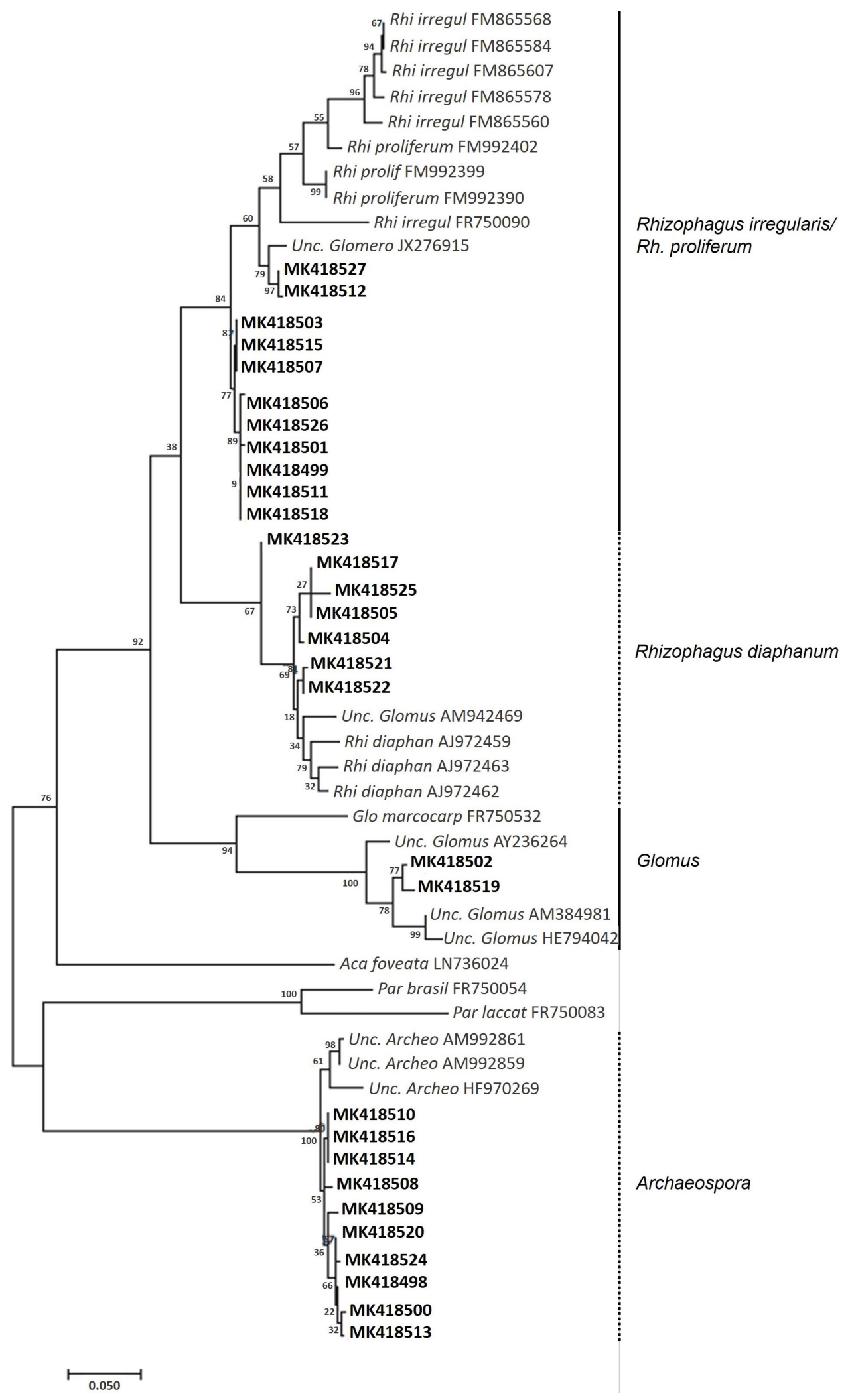

Figure 3. Molecular phylogenetic analysis by Maximum Likelihood method representing SSU-ITS-LSU rDNA sequences of Glomeromycotina fungi colonizing Mimosa pigra flooded roots at La Mixtequilla wetland. Four identified ribotypes are indicated. 
The native plant from the tropics, $M$. pigra, is present in different ecosystems. Members of Fabaceae are highly mycotrophic, mainly when environmental conditions threaten plant development (Azcón 2000). Considering that M. pigra demonstrated high levels of root colonization by AMF in the freshwater wetland under study $(\mathrm{M}=7-61 \%$; $\mathrm{A}=$ up to $17.7 \%$ ), it can be postulated that AMF could facilitate the spread of this plant species, as suggested for Ambrosia artemisiifolia growing in disturbed sites (Fumanal et al. 2006). In addition, $M$. pigra also interacts with nitrogen-fixing bacteria harboring in root nodules (Parker et al. 2007). These bacteria, together with AMF, might render this plant species highly competitive for colonizing stressful environments conferring a better nutritional status. AMF colonization in some Mimosa species is required for enhancing root nodulation (Lammel et al. 2015).

In this wetland, it was observed that properties prevailing in the water column influence fungal root colonization. High temperatures tended to reduce fungal colonization by $\mathrm{AMF}$ and DSE in both plants (M and $\mathrm{C}$ in $C$. articulatus, and $\mathrm{C}$ and MS in $M$. pigra), and DSE appeared to be more susceptible than AMF to high temperatures. Within this context, plant-root colonization by $\mathrm{AMF}$ was reduced when the temperature exceeded $30{ }^{\circ} \mathrm{C}$; elevated temperatures might increase plant night respiration resulting in diminished photosynthate for root-inhabiting fungi (Zhu et al. 2011). High concentrations of dissolved $\mathrm{O}_{2}$ in the water column favored higher $\mathrm{M}$ and $\mathrm{C}$ in $\mathrm{C}$. articulatus; the negative correlation between dissolved $\mathrm{O}_{2}$ in the water column and $\mathrm{M}$ and $\mathrm{A}$ in $M$. pigra could suggest a particular root physiology for supplying dissolved $\mathrm{O}_{2}$. A floating growth habit and aerenchyma are root adaptations described in $M$. pigra living in a flooded environment in a neotropical ecosystem (James et al. 2001). Finally, the negative correlation in $C$. articulatus between $\mathrm{C}$ and the orthophosphate concentration could indicate that DSE are not involved in P nutrition in this plant. In contrast, concentrations of orthophosphates in the water column at El Llanete, which correlated positively with A in $M$. pigra, pointed out the role of AMF in transferring $\mathrm{P}$ from soils and/or the column water to the plant, even under suboxic conditions.

Molecular identification of AMF in Mimosa pigra roots. This is the first time, to the best of our knowledge, in which an AMF community of flooded roots from the shrub $M$. pigra established in a freshwater wetland was molecularly identified. Arbuscules confirmed visually the presence of AMF inside roots; molecular analysis allowed to identify the whole fungal community, constituted by members of Rhizophagus, and Glomus (Order Glomerales), as well as by Archaeospora (Order Archaeosporales). All identified AMF are reported to produce arbuscules; observed vesicles inside roots could belong to Rhizophagus and Glomus since members of Archaeospora do not produce them (Oehl et al. 2011). Glomerales, the largest Order of Glomeromycotina, predominated inside $M$. pigra roots; Glomerales are considered as generalist AMF (Davison et al. 2011). Consistently with results presented here, AMF spores extracted from the rhizosphere soil of colonized native and exotic Fabaceae showed the dominance of Glomerales, but Archaeosporales and Diversisporales were also present (Tibbett et al. 2008). In a recent meta-analysis, Ramírez-Viga et al. (2018) concluded that AMF improve plant performance in wetlands through higher nutrient acquisition, photosynthetic activity, biomass generation, and mitigation of abiotic stress. However, understanding the functionality of AMF in $M$. pigra plants is a future task.

The Neotropics harbor several freshwater intermittent wetlands. Nearly one-hundred known AMF species have been reported in Mexico (Montaño et al. 2012, Chimal-Sánchez et al. 2016, Fabián et al. 2018), considered a high AMF diversity reservoir linked with plant and ecosystem diversity. The Mesoamerican biodiversity hotspot (Myers et al. 2000), where La Mixtequilla wetland is located, certainly harbors a still unknown diversity of AMF that is threatened by habitat destruction and land-use change.

\section{Acknowledgments}

J. Santillán-Manjarrez received a scholarship from CONACyT-Mexico while studying for a master's degree in science. The authors acknowledge Ó. Cano-Flores, J. A. Viccon-Pale (UAM-Xochimilco), and M. G. Medina-Canales (ENCBIPN) for help in soil analysis, and advice during plant sampling and DNA sequence analysis, respectively. A. Meléndez-Herrada (UAM-Xochimilco), and D.P. Janos (University of Miami) provided critical comments on an early version of the manuscript. We thank two anonymous reviewers and Editors for their careful reading of the manuscript, comments and suggestions.

\section{Literature cited}

APHA-WEF [Water Environmental Federation \& American Public Healt Association]. 2005. Standard methods for the examination of water and wastewater. Washington: American Public Health Association. Washington DC, USA. ISBN: 978-0875530475

Azcón R. 2000. Papel de la simbiosis micorrízica y su interacción con otros microorganismos rizosféricos en el crecimiento vegetal y sostenibilidad agrícola. In: Alarcón A, Ferrera-Cerrato R. Eds. Ecología, fisiología y biotecnología de la micorriza arbuscular. Colegio de Posgraduados, pp. 1-15. ISBN: 9789687462233

Calderón de Rzedowski G, Rzedowski J. 2001. Flora fanerogámica del Valle de México. Pátzcuaro: Instituto de Ecología, A.C.-Comisión Nacional para el Conocimiento y Uso de la Biodiversidad. ISBN: 970-9000-17-9

Cejudo-Espinosa E, Ramos-Valdivia AC, Esparza-García F, Moreno-Casasola P, Rodriguez-Vazquez R. 2009. Shortterm accumulation of atrazine by three plants from a wetland model system. Archives of Environmental Contamination and Toxicology 56: 201-208.

DOI: https://doi.org/10.1007/s00244-008-9193-7

Chimal-Sánchez E, Montaño NM, Camargo-Ricalde SL, GarcíaSánchez R, Hernández-Cuevas LV. 2016. Nuevos registros 
de hongos micorrizógenos arbusculares para México. Revista Mexicana de Biodiversidad 87: 242-247.

DOI: https://doi.org/10.1016/j.rmb.2016.01.024

Davison J, Öpik M, Daniell TJ, Moora M, Zobel M. 2011. Arbuscular mycorrhizal fungal communities in plant roots are not random assemblages. FEMS Microbiology Ecology 78: $103-$ 115. DOI: https://doi.org/10.1111/j.1574-6941.2011.01103.x

De Marins JF, Carrenho R, Thomaz SM. 2009. Occurrence and coexistence of arbuscular mycorrhizal fungi and dark septate fungi in aquatic macrophytes in a tropical river-floodplain system. Aquatic Botany 91: 13-19.

DOI: https://doi.org/10.1016/j.aquabot.2009.01.001

Della Monica IF, Saparrat MCN, Godeas AM, Scervino JM. 2015. The co-existence between DSE and AMF symbionts affects plant $P$ pools through $P$ mineralization and solubilization processes. Fungal Ecology 17: 10-17.

DOI: https://doi.org/10.1016/j.funeco.2015.04.004

Dickson S, Smith FA, Smith SE. 2007. Structural differences in arbuscular mycorrhizal symbioses: more than 100 years after Gallaud, where next? Mycorrhiza 17: 375-393. DOI: https://doi.org/10.1007/s00572-007-0130-9

Driessen P, Deckers J, Spaargaren O, Nachtergaele F. (eds). 2001. Lecture notes on the major soils of the world. Food and Agriculture Organization (FAO). ISBN: 925-104637-9

Edgar RC. 2004. MUSCLE: multiple sequence alignment with high accuracy and high throughput. Nucleic Acids Research 32: 1792-1797. DOI: https://doi.org/10.1093/nar/gkh340

Fabián D, Guadarrama P, Hernandez-Cuevas L, Ramos-Zapata JA. 2018. Arbuscular mycorrhizal fungi in a coastal wetland in Yucatan, Mexico. Botanical Sciences 96: 24-34. DOI: https://doi.org/10.17129/botsci.1216

Fuchs B, Haselwandter K. 2004. Red list plants: colonization by arbuscular mycorrhizal fungi and dark septate endophytes. Mycorrhiza 14: 277-281.

DOI: https://doi.org/10.1007/s00572-004-0314-5

Fumanal B, Plenchette C, Chauvel B, Bretagnolle F. 2006. Which role can arbuscular mycorrhizal fungi play in the facilitation of Ambrosia artemisiifolia L. invasion in France? Mycorrhiza 17: 25-35.

DOI: https://doi.org/10.1007/s00572-006-0078-1

García I, Mendoza R, Pomar MC. 2012. Arbuscular mycorrhizal symbiosis and dark septate endophytes under contrasting grazing modes in the Magellanic steppe of Tierra del Fuego. Agriculture, Ecosystems \& Environment 155: 194-201. DOI: https://doi.org/10.1016/j.agee.2012.04.020

Gee GW, Bauder JW. 1986. Particle-size analysis. In: Klute A. Ed. Methods of soil analysis, Part 1: Physical and mineralogical methods. Madison: American Society of Agronomy, 383-412. ISBN: 978-0891188117

DOI: https://doi.org/doi:10.2136/sssabookser5.1.2ed.c15

Gutknecht JLM, Goodman RM, Balser TC. 2006. Linking soil process and microbial ecology in freshwater wetland ecosystems. Plant and Soil 289: 17-34.

DOI: https://doi.org/10.1007/s11104-006-9105-4

Heredia-Acuña C, Alarcón A, Hernández-Cuevas LV, FerreraCerrato R, Almaraz-Suárez JJ. 2014. Diversidad, ecología e importancia potencial de hongos endófitos septados obscuros en México. Botanical Sciences 92: 321-333. DOI: https://doi.org/10.17129/botsci.114
Jackson ML. 1982. Análisis químico de suelos. Barcelona: Omega. ISBN: 84-282-0261-3

James EK, Loureiro MF, Pott A, Pott VJ, Martins CM, Franco AA, Sprent JI. 2001. Flooding-tolerant legume symbioses from the Brazilian Pantanal. New Phytologist 150: 723-738. DOI: https://doi.org/10.1046/j.1469-8137.2001.00126.x

Jumpponen A, Trappe JM. 1998. Dark septate endophytes: a review of facultative biotrophic root-colonizing fungi. New Phytologist 140: 295-310.

DOI: https://doi.org/10.1046/j.1469-8137.1998.00265.x

Junk WJ, Bayley PB, Sparks RE. 1989. The flood pulse concept in river-floodplain systems. In: Dodge DP. Ed. Proceedings of the International Large River Symposium. Ottawa: Canadian Special Publication of Fisheries and Aquatic Sciences 106, Fisheries and Oceans, pp. 110-127. ISBN: 0660132591

Kimura M. 1980. A simple method for estimating evolutionary rates of base substitutions through comparative studies of nucleotide sequences. Journal of Molecular Evolution 16: 111-120. DOI: https://doi.org/10.1007/BF01731581

Kohout P, Sýkorová Z, Ctvrtlíková M, Rydlová J, Suda J, Vohník M, Sudová R. 2012. Surprising spectra of root-associated fungi in submerged aquatic plants. FEMS Microbiology Ecology 80: 216-235.

DOI: https://doi.org/10.1111/j.1574-6941.2011.01291.x

Krüger M, Stockinger H, Krüger C, Schüßler A. 2009. DNAbased species level detection of Glomeromycota: one PCR primer set for all arbuscular mycorrhizal fungi. New Phytologist 183: 212-223.

DOI: https://doi.org/10.1111/j.1469-8137.2009.02835.x

Kumar S, Stecher G, Tamura K. 2016. MEGA7: Molecular Evolutionary Genetics Analysis version 7.0 for bigger datasets. Molecular Biology and Evolution 33: 1870-1874. DOI: https://doi.org/10.1093/molbev/msw054

Kusari S, Hertweck C, Spiteller M. 2012. Chemical ecology of endophytic fungi: origins of secondary metabolites. Chemistry \& Biology 19: 792-798.

DOI: https://doi.org/10.1016/j.chembiol.2012.06.004

Lammel DR, Cruz LM, Mescolotti D, Stürmer SL, Cardoso EJBN. 2015. Woody Mimosa species are nodulated by Burkholderia in ombrophylous forest soils and their symbioses are enhanced by arbuscular mycorrhizal fungi (AMF). Plant and Soil 393: 123-135.

DOI: https://doi.org/10.1007/s11104-015-2470-0

Lonsdale WM. 1993. Rates of spread of an invading species Mimosa pigra in northern Australia. Journal of Ecology 81: 513-521. DOI: https://doi.org/10.2307/2261529

López-Ríos GF, Rosas-López UY. 1988. El herbario. Texcoco: Apoyos Académicos 1, Universidad Autónoma de Chapingo. ISBN: 968-884-803-4

Mandyam KG, Jumpponen A. 2015. Mutualism-parasitism paradigm synthesized from results of root-endophyte models. Frontiers in Microbiology 5: 776.

DOI: https://doi.org/10.3389/fmicb.2014.00776

Matthews GVT. 2013. The Ramsar Convention on Wetlands: its History and Development. Ramsar Convention Secretariat. ISBN: 2-940073-00-7

Medina-Roldán E, Arredondo JT, Huber-Sannwald E, ChapaVargas L, Olalde-Portugal V. 2008. Grazing effects on fun- 
gal root symbionts and carbon and nitrogen storage in a shortgrass steppe in Central Mexico. Journal of Arid Environments 72: 546-556.

DOI: https://doi.org/10.1016/j.jaridenv.2007.07.005

Montaño NM, Alarcón A, Camargo-Ricalde SL, HernándezCuevas LV, Álvarez-Sánchez J, González-Chávez MCA, Gavito ME, Sánchez-Gallen I, Ramos-Zapata J, Guadarrama P, Maldonado-Mendoza IE, Castillo-Argüero S, García-Sánchez R, Trejo D, Ferrera-Cerrato R. 2012. Research on arbuscular mycorrhizae in Mexico: an historical synthesis and future prospects. Symbiosis 57: 111-126.

DOI: https://doi.org/10.1007/s13199-012-0184-0

Moreno-Casasola P, López Rosas H, Infante Mata D, Peralta LA, Travieso-Bello AC, Warner BG. 2009. Environmental and anthropogenic factors associated with coastal wetland differentiation in La Mancha, Veracruz, Mexico. Plant Ecology 200: 37-52.

DOI: https://doi.org/10.1007/s11258-008-9400-7

Muthukumar T, Udaiyan K. 2002. Seasonality of vesicular-arbuscular mycorrhizae in sedges in a semi-arid tropical grassland. Acta Oecologica 23: 337-347.

DOI: https://doi.org/10.1016/S1146-609X(02)01165-7

Muthukumar T, Udaiyan K, Karthikeyan A, Manian S. 1997. Influence of native endomycorrhiza, soil flooding and nurse plant on mycorrhizal status and growth of purple nutsedge (Cyperus rotundus L.). Agriculture, Ecosystems \& Environment 61: 51-58. DOI: https://doi.org/10.1016/S01678809(96)01073-0

Muthukumar T, Udaiyan K, Shanmughavel P. 2004. Mycorrhiza in sedges-an overview. Mycorrhiza 14: 65-77.

DOI: https://doi.org/10.1007/s00572-004-0296-3

Myers N, Mittermeier RA, Mittermeier CG, da Fonseca GAB, Kent J. 2000. Biodiversity hotspots for conservation priorities. Nature 403: 853-858.

DOI: https://doi.org/10.1038/35002501

Newsham KK. 2011. A meta-analysis of plant responses to dark septate root endophytes. New Phytologist 190: 783-793. DOI: https://doi.org/10.1111/j.1469-8137.2010.03611.x

Oehl F, Alves da Silva G, Goto BT, Costa-Maia L, Sieverding E. 2011. Glomeromycota: two new classes and a new order. Mycotaxon 116: 365-379.

DOI: https://doi.org/10.5248/116.365

Olivares E, Vizcaíno D, Gamboa A. 2002. Mineral nutrition of three aquatic emergent macrophytes in a managed wetland in Venezuela. Journal of Plant Nutrition 25: 475-496. DOI: https://doi.org/10.1081/PLN-120003377

Öpik M, Vanatoa A, Vanatoa E, Moora M, Davison J, Kalwij JM, Reier Ü, Zobel M. 2010. The online database Maarj $A M$ reveals global and ecosystemic distribution patterns in arbuscular mycorrhizal fungi (Glomeromycota). New Phytologist 188: $223-241$.

DOI: https://doi.org/10.1111/j.1469-8137.2010.03334.x

Parker MA, Wurtz AK, Paynter Q. 2007. Nodule symbiosis of invasive Mimosa pigra in Australia and in ancestral habitats: a comparative analysis. Biological Invasions 9: 127-138. DOI: https://doi.org/10.1007/s10530-006-0009-2

Parniske M. 2008. Arbuscular mycorrhiza: the mother of plant root endosymbioses. Nature Reviews Microbiology 6: 763775. DOI: https://doi.org/10.1038/nrmicro1987
Phillips JM, Hayman DS. 1970. Improved procedures for clearing roots and staining parasitic and vesicular-arbuscular mycorrhizal fungi for rapid assessment of infection. Transactions of the British Mycological Society 55: 158-161. DOI: https://doi.org/10.1016/S0007-1536(70)80110-3

Ramírez-Viga TK, Aguilar R, Castillo-Argüero S, Chiappa-Carrara X, Guadarrama P, Ramos-Zapata J. 2018. Wetland plant species improve performance when inoculated with arbuscular mycorrhizal fungi: a meta-analysis of experimental pot studies. Mycorrhiza 28: 477-493.

DOI: https://doi.org/10.1007/s00572-018-0839-7

Ramsar Convention Secretariat. 2010. Wetland inventory: a Ramsar framework for wetland inventory and ecological character description. Ramsar handbooks for the wise use of wetlands, 4th edition, vol. 15. Gland: Ramsar Convention Secretariat Bureau.

Rivera-Becerril F, Signoret-Poillon M, Ayala-Zermeño MA, Castilla-Hernández P, García-Mena J, Mier T, Núñez-Cardona MT, Romero-Martínez N, Sánchez-Santillán N, Torres-Corona NC, Viccon-Pale JA. 2008. Algunos aspectos ambientales y biológicos de dos potreros inundables de la Mixtequilla. ContactoS 70: 31-39.

Ruotsalainen AL, Väre H, Vestberg M. 2002. Seasonality of root fungal colonization in low-alpine herbs. Mycorrhiza 12: 2936. DOI: https://doi.org/10.1007/s00572-001-0145-6

Rzedowski J. 1986. Vegetación de México. México DF: Limusa. ISBN: 968-18-0002-8

Sarukhán J, Urquiza-Haas T, Koleff P, Carabias J, Dirzo R, Ezcurra E, Cerdeira-Estrada S, Soberón J. 2015. Strategic actions to value, conserve, and restore the natural capital of megadiversity countries: the case of Mexico. BioScience $\mathbf{6 5}$ : 164-173. DOI: https://doi.org/10.1093/biosci/biu195

Smith SE, Read DJ. 2008. Mycorrhizal symbiosis. London: Academic Press and Elsevier. ISBN: 9780123705266

Spatafora JW, Chang Y, Benny GL, Lazarus K, Smith ME, Berbee ML, Bonito G, Corradi N, Grigoriev I, Gryganskyi A, James TY, O’Donnell K, Roberson RW, Taylor TN, Uehling J, Vilgalys R, White MM, Stajich JE. 2016. A phylum-level phylogenetic classification of zygomycete fungi based on genome-scale data. Mycologia 108: 1028-1046. DOI: https://doi.org/10.3852/16-042

Sraj-Krzic N, Pongrac P, Klemenc M, Kladnik A, Regvar M, Gaberscik A. 2006. Mycorrhizal colonisation in plants from intermittent aquatic habitats. Aquatic Botany 85: 331-336. DOI: https://doi.org/10.1016/j.aquabot.2006.07.001

Stork NE, Habel JC. 2014. Can biodiversity hotspots protect more than tropical forest plants and vertebrates? Journal of Biogeography 41: 421-428.

DOI: https://doi.org/10.1111/jbi.12223

Sudová R, Rydlová J, Ctvrtlíková M, Havránek P, Adamec L. 2011. The incidence of arbuscular mycorrhiza in two submerged Isoëtes species. Aquatic Botany 94: 183-187. DOI: https://doi.org/10.1016/j.aquabot.2011.02.003

Thomaz SM, Mormul RP, Michelan TS. 2015. Propagule pressure, invasilibity of freshwater ecosystems by macrophytes and their ecological impacts: a review of tropical freswater ecosystems. Hydrobiologia 746: 39-59.

DOI: https://doi.org/10.1007/s10750-014-2044-9 
Tibbett M, Ryan MH, Barker SJ, Chen Y, Denton MD, Edmonds-Tibbett T, Walker C. 2008. The diversity of arbuscular mycorrhizas of selected Australian Fabaceae. Plant Biosystems 142: 420-427.

DOI: https://doi.org/10.1080/11263500802151124

Trouvelot A, Kough JL, Gianinazzi-Pearson V. 1986. Measure du taux de mycorhisation VA d'un systeme radiculaire. Recherche de méthodes d'estimation ayant une signification fonctionelle. In: Gianinazzi-Pearson V, Gianinazzi S. eds. Mycorrhizae: physiology and genetics. Paris: INRA Press, pp. 217-221.

USDA [United States Department of Agriculture]. 2004. Soil survey laboratory methods manual. Lincoln: Soil Survey Investigations Report No 42, version 4.0. Burt R ed. U.S Department of Agriculture, Natural Resources Conservation Service.

USDA. 2011. Soil survey laboratory information manual. Lincoln: Soil Survey Investigations Report No. 45, version 2.0, Soil Survey Staff. Burt R. ed. U.S. Department of Agriculture, Natural Resources Conservation Service.

Vandenkoornhuyse P, Baldauf SL, Leyval C, Straczek J, Young PJW. 2002. Extensive fungal diversity in plant roots. Science 295: 2051.

DOI: https://doi.org/10.1126/science.295.5562.2051

Associated editor: Alejandro Zavala Hurtado

Author Contributions: JSM and APSH designed, set up the experiment and analyzed the data. PCH analyzed the data and helped to write the paper. IEMM and DvT were involved on molecular and bioinformatic analysis. GVC participated in soil analysis; $\mathrm{ACH}$ and CHD identified the plant species. MSP gave advice during the field work. FRB designed the experiment, analyzed the data and wrote the paper. van der Valk AG. 2012. The biology of freshwater wetlands. Oxford: Oxford University Press. ISBN: 9780199608942

Viccon-Pale JA, Ortega P, Mendoza-Vargas L, Castilla-Hernández P, López-Cuevas A, Meléndez-Herrada A, Rivera-Becerril F, Vela-Correa G, Signoret-Poillon M. 2016. Structure and population dynamics of the secondary burrower crayfish Procambarus acanthophorus from a tropical Mexican wetland. Canadian Journal of Zoology 94: 479-488. DOI: https://doi.org/10.1139/cjz-2015-0181

Waterhouse AM, Procter JB, Martin DMA, Clamp M, Barton GJ. 2009. Jalview Version 2-a multiple sequence alignment editor and analysis workbench. Bioinformatics 25 : 11891191. DOI: https://doi.org/10.1093/bioinformatics/btp033

Weishampel PA, Bedford BL. 2006. Wetland dicots and monocots differ in colonization by arbuscular mycorrhizal fungi and dark septate endophytes. Mycorrhiza 16: 495-502. DOI: https://doi.org/10.1007/s00572-006-0064-7

Zhu X-C, Song F-B, Liu S-Q, Liu TD. 2011. Effects of arbuscular mycorrhizal fungus on photosynthesis and water status of maize under high temperature stress. Plant and Soil 346: 189-199. DOI: https://doi.org/10.1007/s11104-011-0809-8 